\title{
PERANCANGAN KEMASAN BUAH SALAK SEGAR DALAM BENTUK TANDAN (SALAK PONDOH BANJARNEGARA, JAWA TENGAH)
}

\section{DESIGN PACKAGING OF THE BUNCHES FRESH SNAKE FRUIT (PONDOHSNAKE FRUIT OF BANJARNEGARA, CENTRAL JAVA)}

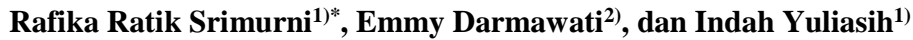 \\ ${ }^{1)}$ Departemen Teknologi Industri Pertanian, Fakultas Teknologi Pertanian, Institut Pertanian Bogor \\ Kampus IPB Darmaga, Bogor 16680, Indonesia \\ E-mail: rafikaratiksm@gmail.com \\ ${ }^{2)}$ Departemen Teknik Mesin dan Biosistem, Fakultas Teknologi Pertanian, Institut Pertanian Bogor \\ Makalah: Diterima 7 Februari 2018; Diperbaiki 7Agustus 2018; Disetujui 19 Agustus 2018
}

\begin{abstract}
The bunches snake fruit has an unique form that become a typical appeal for the customerand also improve the marketing that rarely available, because of the limited form of packaging. It needs to be supported by primary and secondary packaging. The aim of this research was to obtain the primary and secondary packaging designs of the bunches snake fruit with the additional of the net foam. The corrugated cardboard $C$ flute (RSC type) and BC flute (PTD type) were used as the material for the primary and secondary packagings. The ventilation holes was given for air circulation. The steps of this research were to design the dimension of primary and secondary packaging for the bunches snake fruit, to measure the compressive strength and maximum number of packaging stacks, and to analyze the efficiency of packaging arragement on the pallet and in a pickup. The dimensions of primary packaging was $15.98 \times 15.98 \times 18.48 \mathrm{~cm}$ that has a maximum compressive strength of $65 \mathrm{kgf}$ to stacks 23-43 packs. The dimensions of secondary packaging were50.04 $\times 34.06 \times 28.54 \mathrm{~cm}$ (body), and $52.84 \times 36.86 \times 14.97 \mathrm{~cm}$ (cover) that has the maximum compressive strength of $132.2 \mathrm{kgf}$ was capable to hold 3-4 stacks. The dimensions of secondarypackaging were included in good fit efficiency in pick-up and average fit on pallet (size $1200 \times 800$ and $1140 \times 1140 \mathrm{~mm}$ ), so it can supplied for local and export distribution needs to some European contries, Singapore, and China.
\end{abstract}

Keywords: snake fruit, bunch, packaging design, corrugated box, transportation packaging

\section{ABSTRAK}

Salak dalam bentuk tandan memiliki bentuk unik yang menjadi daya tarik bagi konsumen dan juga meningkatkan pemasaran yang jarang tersedia karena terbatasnya bentuk kemasan. Pemasaran salak tandan perlu didukung oleh kemasan primer dan sekunder. Tujuan dari penelitian ini adalah untuk memperoleh desain kemasan primer dan sekunder salak tandan dengan penambahan net foam. Karton gelombang flute $\mathrm{C}$ (tipe RSC)dan karton gelombang flute BC (tipe PTD) digunakan sebagai bahan kemasan primer dan sekunder. Kemasan diberi ventilasi untuk sirkulasi udara. Tahapan dari penelitian ini yaitu mendesain dimensi kemasan primer dan sekunder untuk satu tandan salak, pengukuran nilai kuat tekan dan jumlah tumpukan maksimum kemasan, serta menganalisis efisiensi kemasan pada paletdan pada mobil pickup. Kemasan primer hasil rancangan berukuran $15,98 \times 15,98 \times 18,48 \mathrm{~cm}$ yang mempunyai nilai kuat tekan maksimum sebesar $65 \mathrm{kgf}$ mampu menumpuk 23-43 kemasan primer. Dimensi kemasan sekunder berukuran 50,04 × 34,06 $\times 28,54 \mathrm{~cm}$ (body) dan 52,84 $\times 36,86 \times 14,97 \mathrm{~cm}$ (cover) yang mempunyai nilai kuat tekan maksimum sebesar 132,2 $\mathrm{kgf}$ mampu menahan 3-4 tumpukan kemasan sekunder.Dimensi kemasan sekundertermasuk ke dalam good fit efisiensi pada pick-up dan average fit pada pallet (ukuran $1200 \times 800$ dan $1140 \times 1140 \mathrm{~mm}$ ), sehingga dapat memenuhi kebutuhan untuk distribusi lokal maupun ekspor ke beberapa negara Eropa, Singapura, dan China.

Kata kunci: salak, tandan, desain kemasan, kardus, kemasan transportasi

\section{PENDAHULUAN}

Salak merupakan salah satu produk pertanian yang menjadi fokus buah eksport Indonesia dalam rencana strategis Kementerian Pertanian tahun 2015-2019. Potensi peningkatan pasar salak menjadi semakin luas dengan adanya rencana strategis ini. Produktivitas salak mengalami peningkatan tiap tahunnya dengan rerata pertumbuhan 8,89\% pada tahun 2010-2014. Produksi buah salak menempati urutan kelima dengan produksi sekitar 5,65\% terhadap total produksi buah nasional. Sentra produksi salak terdapat di Jawa Tengah dengan produksi sebesar 441.841 ton (sekitar 39,49\% dari total produksi salak nasional) disusul oleh Provinsi DI Yogyakarta, Jawa Barat dan Jawa Timur. Tahun 2014 terjadi penurunan produksi salak di Jawa Tengah sebesar 9823 ton. Penurunan produksi salak disebabkan karena banyak petani yang beralih menggunakan pupuk organik sehingga salak lebih rentan terhadap ulat dan natona. Kondisi seperti ini menjadi peluang 
untuk peningkatan pasar salak organik (Kementerian Pertanian, 2015).

Banjarnegara merupakan salah satu sentra produksi salak, namun masyarakat Indonesia masih belum begitu mengenal nama salak Banjarnegara. Buah salak yang dominan dikenal masyarakat yaitu salak pondoh Sleman Yogyakarta, padahal pemenuhan pasar untuk salak pondoh banyak dari Banjarnegara. Hal ini menjadi tantangan bagi petani Banjarnegara untuk terus mengangkat nama salak unggulan daerah mereka. Petani salak pondoh di Banjarnegara sudah mulai menerapkan sistem pemupukan organik sehingga salak yang dihasilkan lebih sehat untuk dikonsumsi. Pemasaran salak pondoh organik Banjarnegara belum mendapat perhatian dari konsumen, oleh karena itu tercipta gagasan untuk mengembangkan cara penjualan salak sehat dengan kemasan yang unik.

Buah salak mempunyai pola respirasi nonklimakterik dan laju transpirasi yang tinggi. Buah salak mempunyai sifat mudah rusak dan berumur simpan pendek salah satunya karena luka mekanis akibat terlepasnya salak dari tandan. Pelepasan buah dari tandan ini dapat mengakibatkan terjadinya luka pada bagian pangkal buah berupa terkelupasnya kulit buah salak. Proses respirasi dipercepat dengan adanya luka pada buah (Sutrisno et al., 2011). Pengiriman salak dalam bentuk tandan dapat mengurangi kerusakan buah salak serta mempunyai umur simpan yang lebih lama dibandingkan dengan salak pipilan. Trisnawati dan Rubiyo (2004) melaporkan bahwa salak dalam bentuk tandan mampu mempertahankan kesegaran buah selama 12 hari sedangkan menurut Adiharmanto et al. (2013) salak bentuk pipilan mempunyai umur simpan selama 6 hari.

Salak dalam bentuk tandan akan menjadi daya tarik bagi konsumen karena bentuknya yang unik. Hal ini dapat menjadi inovasi cara penjualan salak dalam bentuk tandan selain karena umur simpan yang lebih lama juga mempunyai nilai tambah dalam tampilan. Salak tandan perlu perlakuan khusus agar tidak mudah terlepas dari tandannya dan dapat melindungi buah. Salah satu caranya yaitu dengan penggunaan kemasan individu berupa karton gelombang (kardus) dan kemasan pelindung (net foam). Penggunaan net foam selain untuk mencegah kerusakan fisik akibat benturan juga untuk menambah estetika dari tampilan salak dalam bentuk tandan, sedangkan penggunaan karton bertujuan untuk mengurangi kerusakan mekanis selama transportasi, seperti yang telah dikaji oleh Sutrisno et al. (2011). Hasil penelitian menunjukkan bahwa dengan penggunaan karton gelombang (kardus) yang sesuai dengan volume buah dapat menekan kerusakan mekanis lebih besar dibandingkan dengan kemasan dengan kapasitas besar. Oleh karena itu pada penelitian ini dirancang kemasan primer yang sesuai dengan volume buah salak dalam satu tandan serta diberi ventilasi untuk penyebaran suhu di dalam kemasan.

Perancangan kemasan yang digunakan untuk mengemas individu buah salak tandan yaitu berupa kemasan pelindung (net foam), kemasan primer (kemasan ritel) dan kemasan sekunder (kemasan transportasi) berbahan karton gelombang. Napitupulu (2001) menyatakan bahwa buah salak yang dikemas menggunakan kardus mengalami kerusakan mekanis lebih kecil (14,3\%) dibandingkan dengan kemasan karung (26,3\%-29,8\%). Perancangan kemasan primer dan sekunder ini bertujuan untuk menghasilkan konsep kemasan yang mampu mempertahankan salak dalam bentuk tandan selama proses distribusi dan pemasarannya.

Perancangan sistem transportasi kemasan salak tandan perlu dilakukan untuk menunjang persiapan ekspor yang direncanakan Kementerian Pertanian. Penelitian ini merancang dan menganalisis efisiensi susunan dan tumpukan kemasan diatas mobil pick up (sebagai alat transportasi lokal) dan di atas pallet kayu sebagai model pengiriman untuk mempermudah ekspor.

Tujuan utama dari penelitian ini adalah merancang kemasan buah salak dalam bentuk tandan yang terdiri dari kemasan pengisi, kemasan primer, dan kemasan sekunder. Sementara tujuan khusus dari penelitian ini adalah 1) merancang desain kemasan buah salak dalam bentuk tandan yang terdiri dari kemasan pelindung, kemasan primer dan kemasan sekunder; dan 2) menganalisis efisiensi susunan kemasan di atas pallet kayu dan mobil pick up.

\section{BAHAN DAN METODE}

\section{Bahan dan Alat}

Bahan yang digunakan dalam penelitian ini yaitu salak pondoh organik Banjarnegara (daerah atas) dengan tingkat kematangan $80 \%$ (umur panen 5 - 6 bulan setelah penyerbukan), net foam, kemasan primer berbahan karton gelombang flute $\mathrm{C}$ (double face) dan kemasan sekunder tipe flute $\mathrm{BC}$ (double wall), serta tali pandan untuk kemudahan membawa kemasan primer. Peralatan yang digunakan terdiri dari timbangan, meteran, pallet, dan mobil pick up

\section{Jenis dan Sumber Data}

Jenis data yang digunakan dalam penelitian ini berupa data primer yang bersifat kuantitatif. Data penelitian diperoleh dari hasil pengukuran dan wawancara dengan petani salak di Banjarnegara.

\section{Tahapan Penelitian}

Penelitian terdiri atas 3 (tiga) tahap yang disajikan pada Gambar 1, yaitu :

1) Merancang sistem kemasan buah salak dalam bentuk tandan yang terdiri dari kemasan pengisi, kemasan primer dan kemasan sekunder 


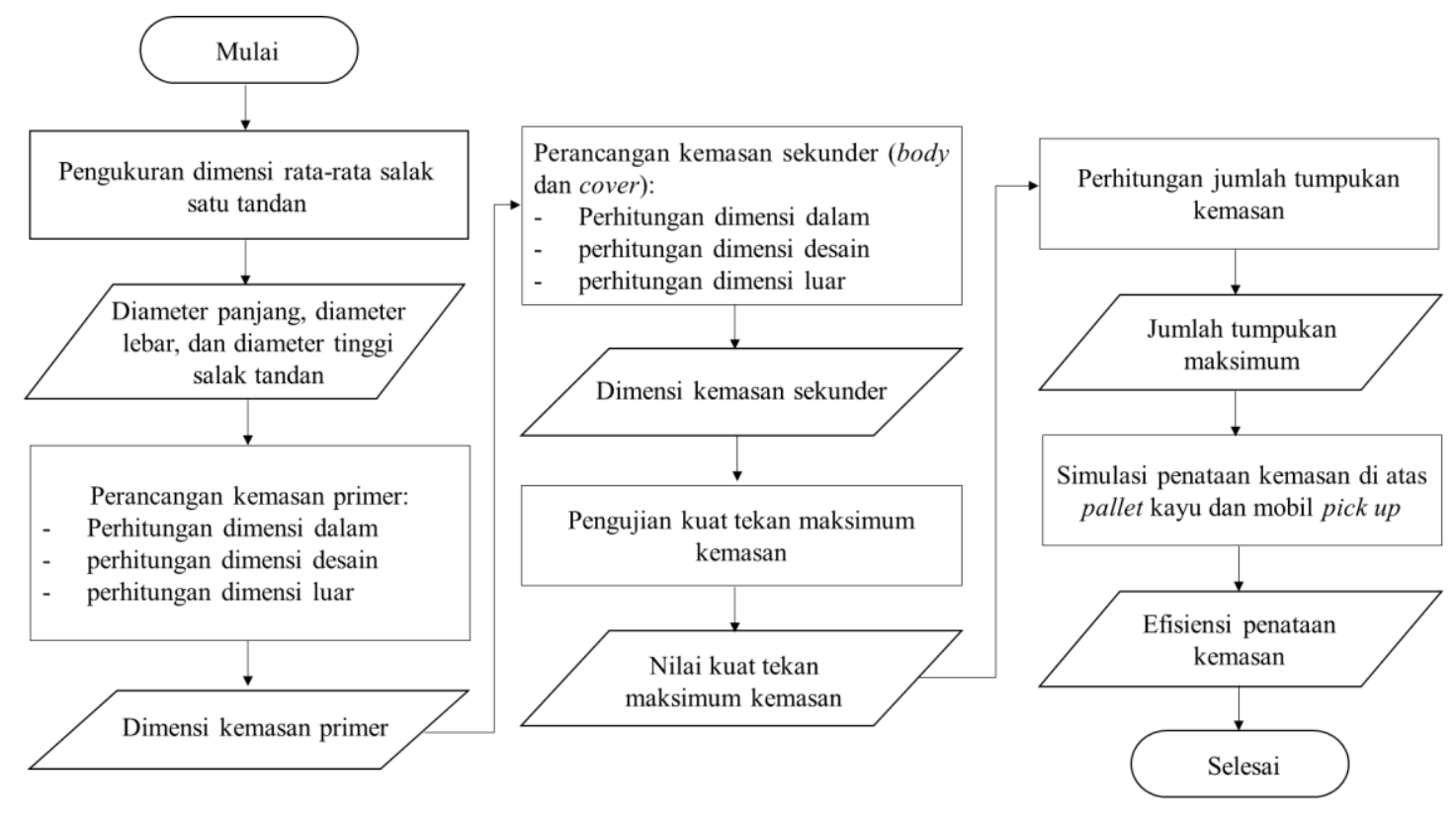

Gambar 1. Tahapan penelitian

2) Menganalisis jumlah tumpukan kemasan hasil rancangan

3) Menganalisis efisiensi susunan kemasan di atas pallet kayu dan mobil pick up.

\section{Pengukuran Bobot dan Dimensi Buah Salak}

Bobot salak dalam satu tandan diukur menggunakan timbangan digital ketelitian 1 gram. Dimensi buah salak diasumsikan mendekati bentuk lingkaran, sehingga diameter panjang dan diameter lebar diasumsikan sama. Buah salak tandan diukur keliling lebar dan keliling tinggi menggunakan meteran untuk mengetahui diameter lebar $\left(D_{L}\right)$ dan diameter tinggi $\left(D_{T}\right)$ menggunakan persamaan 1 dan 2. Pengukuran diameter salak dapat dilihat pada Gambar 2.

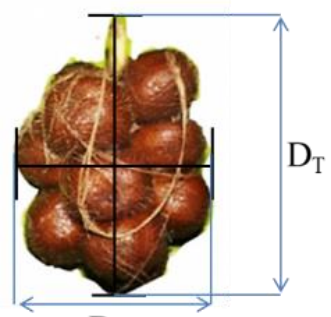

$\mathrm{D}_{\mathrm{L}}$

Gambar 2. Pengukuran diameter buah salak dalam bentuk tandan

$$
\begin{aligned}
& K_{L}=2 \times \pi \times\left(1 / 2 D_{L}\right) \\
& K_{T}=2 \times \pi \times\left(1 / 2 D_{T}\right)
\end{aligned}
$$

\section{Keterangan :}

$\begin{array}{llll}K_{L} & =\text { keliling lebar; } & D_{T} & =\text { diameter tinggi } \\ K_{T} & =\text { keliling tinggi; } & D_{L} & =\text { diameter lebar } \\ \pi & =\text { phi }=3,14 & & \end{array}$

\section{Perancangan Kemasan Primer}

Kemasan primer untuk salak dalam bentuk tandan yang dirancang yaitu berbahan karton gelombang double face menggunakan flute $\mathrm{C}$ tipe RSC (Regular Selotted Carton) yang diberi tali untuk kemudahan dalam membawa. Kemasan diberi ventilasi berbentuk lingkaran dengan luasan 2\% dari luas kemasan (Tawakal et al., 2016). Jumlah ventilasi sebanyak 8 (delapan) lubang, dua lubang masing-masing pada bagian panjang dan lebar kemasan. Tahapan untuk perancangan kemasan primer yaitu penentuan dimensi dalam, perhitungan dimensi desain, dan perhitungan dimensi luar.

\section{Penentuan Dimensi Dalam}

Salak dalam bentuk tandan dibungkus dengan kemasan pengisi (net foam) yang dilipat menjadi dua lipatan (net foam) tidak menutupi seluruh tinggi buah). Penentuan dimensi dalam mengacu pada diameter lebar $\left(\mathrm{D}_{\mathrm{L}}\right)$ dan diameter tinggi $\left(\mathrm{D}_{\mathrm{T}}\right)$ salak tandan yang tersaji pada Gambar 3 .
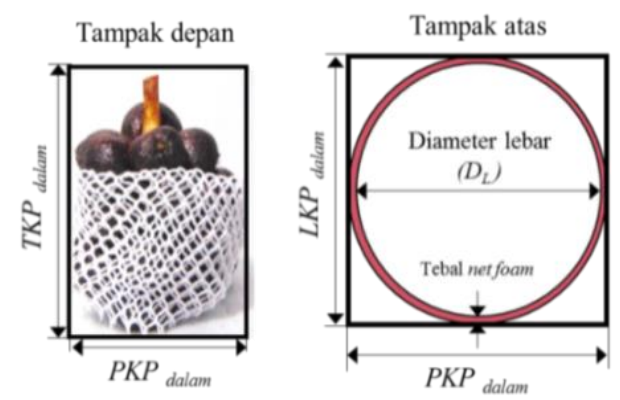

Gambar 3. Penentuan dimensi dalam kemasan primer untuk satu tandan salak

$P K P_{\text {dalam }}=D_{L}+(4 \times$ tebal net foam $)$ 
$L K P_{\text {dalam }}=D_{L}+(4 \times$ tebal net foam $)$

TKP $P_{\text {dalam }}=D_{T}$

Keterangan :

$P K P \quad=$ panjang kemasan primer

$L K P=$ lebar kemasan primer

$T K P \quad=$ tinggi kemasan primer

Perhitungan Dimensi Desain

Dimensi desain merupakan penjumlahan dari dimensi dalam dengan tebal flute kemasan. Dimensi desain untuk karton gelombang flute $\mathrm{C}$ tipe RSC dihitung dengan persamaan-persamaan berikut. Penentuan dimensi desain dapat dilihat pada Gambar 4.

$P K P_{\text {desain }}=P K P_{\text {dalam }}+$ tebal flute $C$

$L K P_{\text {desain }}=L K P_{\text {dalam }}+$ tebal flute $C \ldots \ldots \ldots \ldots$

$T K P_{\text {desain }}=T K P_{\text {dalam }}+(2 \times$ tebal flute $C) \ldots .$.

$f=\left(L K P_{\text {desain }}+\right.$ tebal flute $\left.C\right) / 2$

$x^{\prime}=P K P_{\text {desain }}-(2 \times$ tebal flute $C)$

$y^{\prime}=L K P_{\text {desain }}-(2 \times$ tebal flute $C)$

\section{Keterangan :}

$F \quad=$ tinggi flap kemasan

$x^{\prime}=$ lebar flap kemasan

$\mathrm{y}^{\prime} \quad=$ lebar flap kemasan

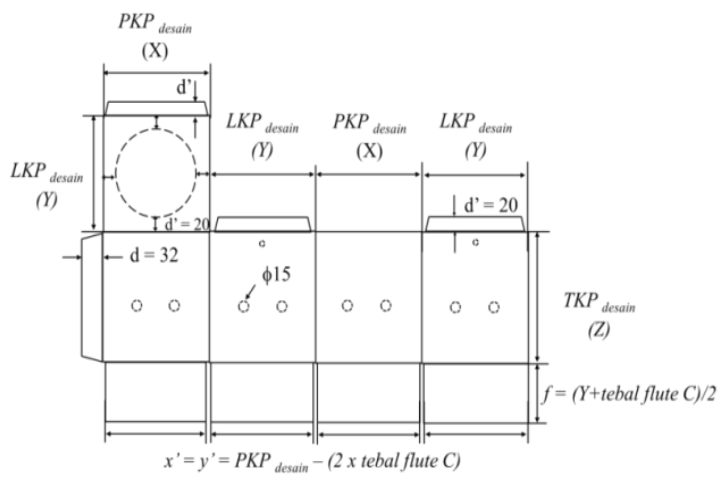

Gambar 4. Penentuan dimensi desain kemasan primer

\section{Perhitungan Dimensi Luar Kemasan}

Dimensi luar kemasan dihitung berdasarkan tipe flute dan ketebalan karton gelombang yang digunakan. Perhitungan dimensi luar merupakan penjumlahan dari dimensi desain dengan ketebalan flute C. Perhitungan dimensi luar kemasan dapat dilihat pada Gambar 5.
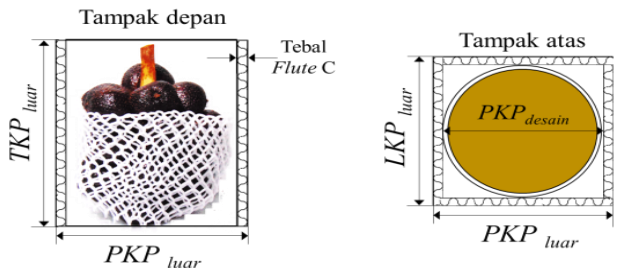

Gambar 5. Penentuan dimensi luar kemasan primer untuk satu tandan salak

$P K P_{\text {luar }}=P K P_{\text {desain }}+(2 \times$ tebal flute $C) \ldots$.

$$
\begin{aligned}
& L K P_{\text {luar }}=L K P_{\text {desain }}+(2 \times \text { tebal flute } C) \ldots . \\
& T K P_{\text {luar }}=T K P_{\text {desain }}+(2 \times \text { tebal flute } C) \ldots .
\end{aligned}
$$

\section{Perancangan Kemasan Sekunder}

Kemasan sekunder untuk salak satu tandan yang dirancang yaitu berbahan karton gelombang double wall flute $\mathrm{BC}$ tipe PTD (Partial-Telescope Design-Style Box). Kemasan diberi ventilasi berbentuk lingkaran menyesuaikan dengan ventilasi kemasan primer serta diberi lubang tangan ukuran 85 $\mathrm{mm}$ x $25 \mathrm{~mm}$ untuk mempermudah pengangkutan (Singh et al., 2008).

\section{Penentuan Dimensi Dalam}

Penentuan dimensi dalam kemasan sekunder mengacu pada jumlah kemasan primer dalam kemasan sekunder. Penelitian ini menggunakan 6 (enam) kemasan primer dalam satu kemasan sekunder. Penentuan dimensi dalam kemasan sekunder dapat dilihat pada Gambar 6.
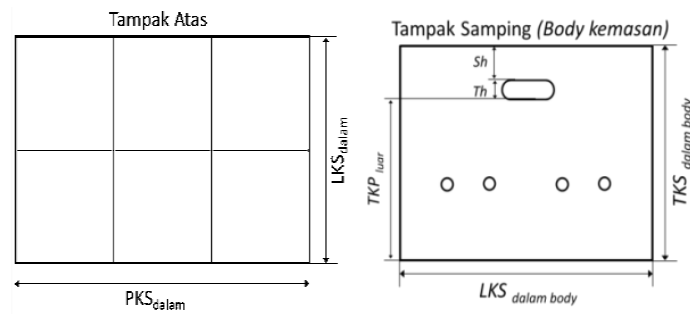

Gambar 6. Penentuan dimensi dalam kemasan sekunder

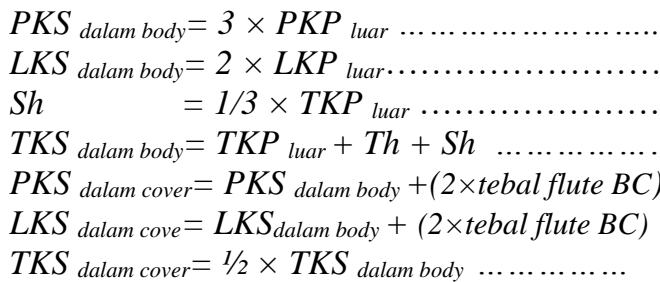

Keterangan:
$P K S$
$=$ panjang kemasan sekunder
$L K S \quad=$ lebar kemasan sekunder
$T K S=$ tinggi kemasan sekunder
Th = tinggi hand hole
Sh = jarak head kemasan dengan hand hole

\section{Perhitungan Dimensi Desain}

Dimensi desain merupakan penjumlahan antara dimensi dalam kemasan sekunder dengan tebal flute BC. Dimensi desain untuk tipe kemasan PTD double wall dibedakan menjadi dua perhitungan, yaitu perhitungan desain body (Gambar 7) dan perhitungan desain cover kemasan (Gambar 8).

$P K S_{\text {desain body }}=P K S_{\text {dalam body }}+$ tebal flute $B C \ldots$ (22)

$L K S_{\text {desain body }}=L K S_{\text {dalam body }}+$ tebal flute $B C \ldots$ (23)

$T K S_{\text {desain body }}=T K S_{\text {dalam body }}+$ tebal flute BC 

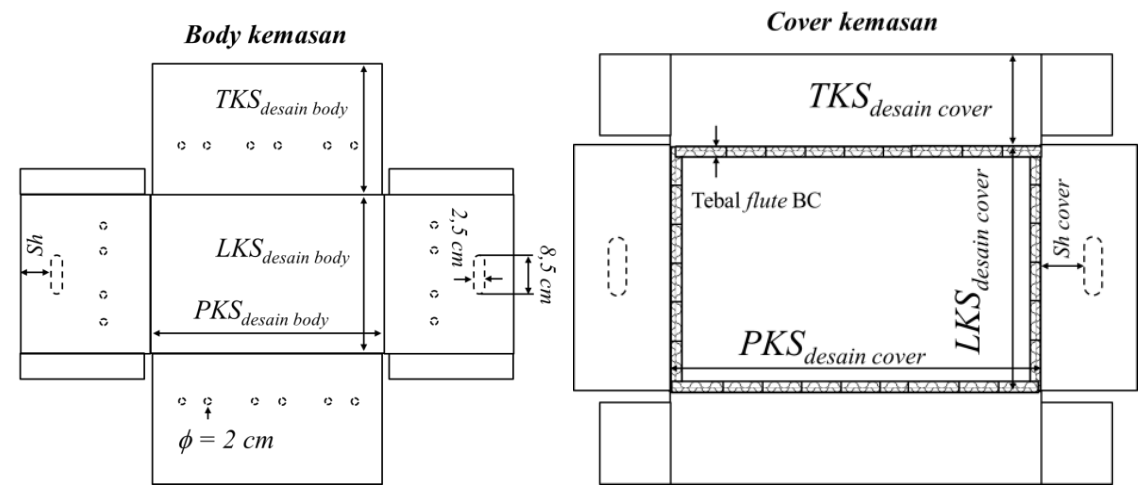

Gambar 7. Penentuan dimensi desain kemasan sekunder

$$
\begin{aligned}
P K S_{\text {desain cover }} & =P K S_{\text {dalam cover }}+\text { tebal flute } B C \ldots \\
L K S_{\text {desain cover }} & =L K S_{\text {dalam cover }}+\text { tebal flute } B C \ldots \\
S_{\text {cover }} & =S h+\text { tebal flute } B C \ldots \ldots \ldots \ldots \ldots \\
T K S_{\text {desain cover }} & =T K S_{\text {dalam cover }}+\text { tebal flute } B C . .
\end{aligned}
$$

\section{Perhitungan Dimensi Luar}

Perhitungan dimensi luar merupakan penjumlahan dari dimensi desain kemasan sekunder dengan dua kali ketebalan flute BC (Gambar 8). Perhitungan dimensi luar body kemasan disajikan dalam persamaan berikut:
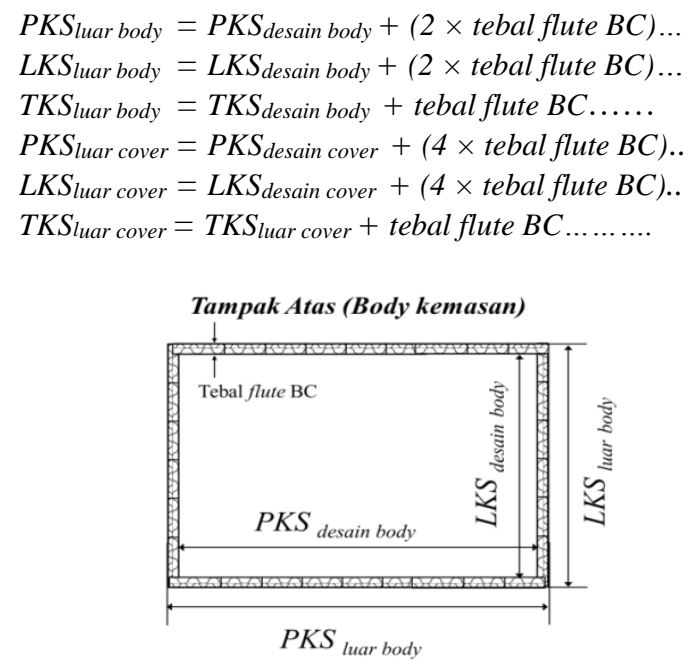

(a)

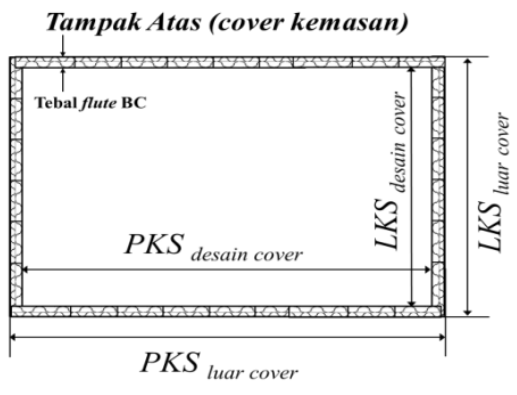

(b)

Gambar 8. Penentuan dimensi luar kemasan sekunder (a) body, (b) cover
Pengujian Beban Tekan Maksimum dan Tumpukan Kemasan

Kemasan hasil rancangan selanjutnya dilakukan pengujian kuat tekan kemasan (compression strength) menggunakan alat Universal Testing MachineChun Yen. Pengujian kekuatan tekan ditambahkan tatakan kayu untuk penyebaran gaya. Kecepatan yang digunakan untuk pengujian sebesar $10 \mathrm{~mm} /$ menit. Perhitungan jumlah tumpukan kemasan dihitung dengan persamaan Selke (2005) yaitu :

$$
\begin{aligned}
S F & =\frac{P}{f} \\
T_{K} & =\frac{S F}{W}
\end{aligned}
$$

Dimana :

$$
\begin{array}{ll}
\text { SF } & =\text { Safe load on box } \\
P & =\text { Compression strength } \\
f & =\text { Nilai koefisien keselamatan }=2 \\
T_{K} & =\text { jumlah tumpukan kemasan } \\
W & =\text { berat total kemasan }
\end{array}
$$

\section{Efisiensi Penataan Kemasan untuk Transportasi}

Perhitungan efisiensi penataan kemasan pada satuan handling seperti pallet dan bak pick-up perlu dilakukan untuk memaksimalkan pengiriman. Nilai efisiensi penataan kemasan pada pallet dan bak pick-up dihitung menggunakan persamaan 37.

$$
E_{f}=\frac{J_{k} \times L_{k}}{L_{p}} \times 100
$$

Dimana :

Ef = efisiensi penataan kemasan di atas pallet atau bak pick-up $(\%)$

$J_{k} \quad=$ jumlah kemasan tersusun

$L_{k} \quad=$ luas cover kemasan sekunder

$L_{p} \quad$ = luas pallet / bak pick-up

\section{HASIL DAN PEMBAHASAN}

\section{Karakteristik dan Dimensi Buah Salak Tandan}

Buah salak mempunyai sifat mudah rusak dan berumur simpan pendek, salah satunya disebabkan karena luka mekanis akibat terlepasnya salak dari tandannya. Hal tersebut mamacu tingginya 
transpirasi dan respirasi buah sehingga memperpendek umur simpan (Pangidoan et al., 2013). Penggunaan kemasan kardus dapat melindungi buah salak terhadap kerusakan mekanis dan kondisi lingkungan sehingga dapat menekan laju transpirasi dan respirasi yang berpengaruh terhadap penurunan mutu selama penyimpanan (Iswahyudi et al., 2015). Buah salak yang telah di panen masih melakukan proses kehidupan seperti melakukan pernafasan (respirasi), penguapan (transpirasi), mengalami perubahan kimiawi dan biologis, termasuk juga mengalami serangan organisme tertentu. Buah salak mempunyai pola respirasi nonklimakterik dan laju transpirasi yang tinggi, proses tersebut dapat menurunkan kualitas buah salak pascapanen (Cahyono, 2016). Oleh karena itu perlu mempertimbangkan kebutuhan udara di dalam kemasan untuk mempertahankan mutu buah salak.

Perancangan kemasan kardus perlu dilakukan optimasi ukuran dan proporsi kemasan dimana kemasan harus sesuai dengan volume produk yang dikemas (Dehankar et al., 2014). Ukuran atau volume produk yang akan di kemas mempengaruhi dimensi kemasan yang di rancang. Kemasan yang terlalu banyak ruang kosong akan menimbulkan peluang untuk kerusakan mekanis akibat guncangan dan benturan yang semakin besar, sehingga diperlukan pengukuran dimensi buah terlebih dahulu.

Buah salak tandan yang dipilih untuk pengukuran yaitu buah salak dengan tingkat kematangan $80 \%$ yang mempunyai bobot $1-1,5 \mathrm{~kg}$ tiap tandan. Pengukuran dimensi buah dilakukan pada 6 sampel yang diambil masing-masing 1 tandan salak tiap pohon. Tabel 1 merupakan hasil observasi pengukuran rata-rata dimensi buah salak dalam satu tandan.

Tabel 1. Dimensi salak satu tandan

\begin{tabular}{lcc}
\hline Bagian & Keliling $(\mathbf{c m})$ & Diameter $(\mathbf{c m})$ \\
\hline Lebar & $43,00 \pm 2,61$ & $13,69 \pm 0,83$ \\
Tinggi & $53,50 \pm 2,17$ & $17,04 \pm 0,69$ \\
\hline
\end{tabular}

Hasil pengukuran dimensi buah salak satu tandan dijadikan acuan untuk menentukan perhitungan dimensi kemasan primer yaitu dengan diameter lebar $\left(D_{L}\right) 13,69 \pm 0,83 \mathrm{~cm}$ dan diameter tinggi $\left(D_{T}\right) 17,04 \pm 0,69 \mathrm{~cm}$.

\section{Perancangan Kemasan Primer}

Perancangan kemasan primer diperoleh dengan menentukan dimensi dalam kemasan yaitu dimensi salak satu tandan. Kemasan karton gelombang (kardus) banyak digunakan sebagai kemasan distribusi karena dapat melindungi produk dari kerusakan mekanis akibat benturan, getaran, dan beban kompresi (Pathare et al., 2014). Tahapan dalam merancang kemasan primer terdiri dari tiga tahapan, yaitu menghitung dimensi dalam, dimensi desain, dan dimansi luar (Yulianti et al., 2010). Hasil perhitungan terdapat pada Tabel 2.

Kemasan yang dirancang menggunakan karton gelombang tipe RSC (Regular Seloted Container) flute C kraft 275 gsm dengan inovasi desain pada bagian tutup kemasan. Singh et al. (2009) menyatakan bahwa karton gelombang tipe Regular Selotted Container (RSC) merupakan kemasan yang umum digunakan di pasar. Flute $\mathrm{C}$ dipilih karena mempunyai harga lebih murah tetapi memiliki daya bantalan yang tinggi seperti flute A dan memiliki ketahanan tekan datar seperti flute B (Nordstrand, 2003). Bagian lebar kemasan diberi tali untuk kemudahan dalam membawa. Kemasan primer mempunyai nilai kuat tekan kemasan maksimum 65 kgf dengan jumlah tumpukan maksimum 23-43 kemasan (hasil perhitungan persamaan 35 dan 36). Nilai kuat tekan kemasan berpengaruh terhadap jumlah tumpukan kemasan. Yulianti et al. (2010) menyarankan untuk mengatur jumlah tumpukan agar kemasan pada posisi terbawah tidak mengalami kerusakan yang diakibatkan oleh beban statis dari kemasan diatasnya.

Ventilasi kemasan menggunakan bentuk lingkaran dengan luasan 2 (diameter $1,5 \mathrm{~cm}$ ) masing-masing 2 lubang pada bagian panjang dan lebar kemasan (Gambar 9 dan Gambar 10). Tawakal et al. (2016) menyatakan bahwa nilai kuat tekan kemasan semakin kecil dengan penggunaan luasan ventilasi lebih dari $2 \%$ dari total luas permukaan kemasan, sehingga penelitian ini menggunakan luasan ventilasi $2 \%$ untuk memperoleh kemasan dengan nilai kuat tekan yang tinggi.

Tabel 2. Dimensi kemasan primer hasil rancangan

\begin{tabular}{lccc}
\hline \multirow{2}{*}{ Parameter } & \multicolumn{3}{c}{ Dimensi Kemasan } \\
\cline { 2 - 4 } & Dimensi Dalam & Dimensi Desain & Dimensi Luar \\
\hline Tebal net foam $(\mathrm{cm})$ & 0,30 & & \\
Tebal flute C $(\mathrm{cm})$ & 0,36 & 15,26 & 15,98 \\
\hline Panjang $(\mathrm{cm})$ & 14,90 & 15,26 & 15,98 \\
Lebar $(\mathrm{cm})$ & 14,90 & 17,76 & 18,48 \\
Tinggi $(\mathrm{cm})$ & 17,04 & 232,87 & 255,36 \\
\hline Luas Kemasan $\left(\mathrm{cm}^{2}\right)$ & 222,01 & 4135,73 & 4719,06 \\
Volume kemasan $\left(\mathrm{cm}^{3}\right)$ & 3783,05 & & \\
\hline
\end{tabular}




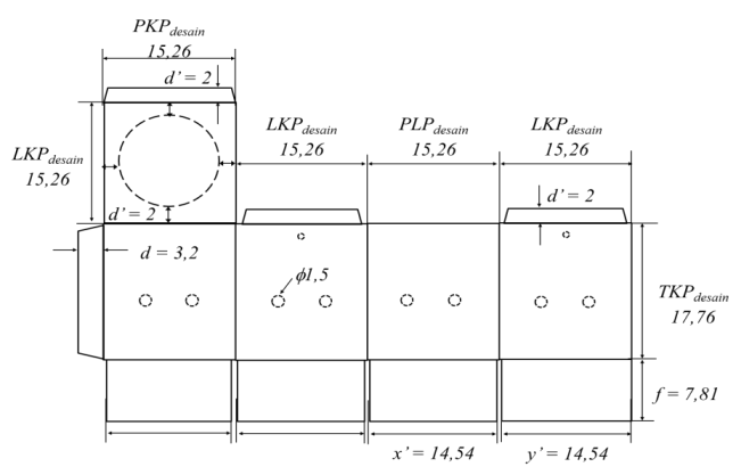

Gambar 9. Dimensi desain kemasan primer hasil perhitungan
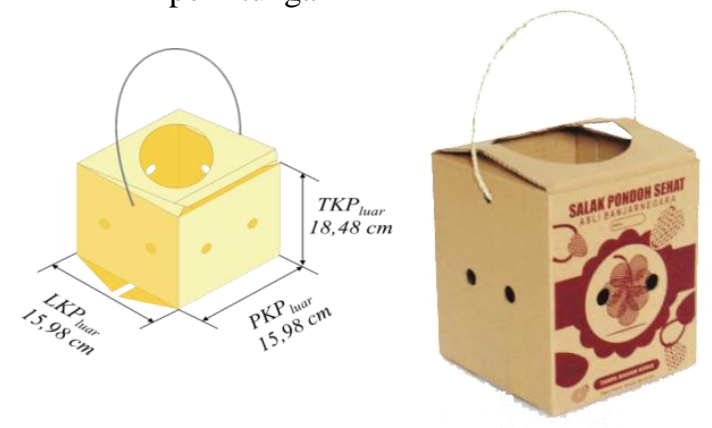

Gambar 10. Dimensi luar kemasan primer

Tipe ventilasi, luasan, dan posisi ventilasi dapat mempengaruhi kekuatan kemasan kardus dan mengakibatkan penurunan mutu buah pascapanen (Pathare dan Opara, 2014). Ventilasi berfungsi untuk mempertahankan distribusi udara yang cukup sesuai dengan kebutuhan produk sehingga perpindahan panas produk ke udara dingin akan menjadi optimal, hal ini dapat mengurangi kerusakan produk selama transportasi (Opara dan Fadiji, 2018).

\section{Perancangan Kemasan Sekunder}

Perancangan kemasan sekunder dimaksudkan untuk mempermudah penanganan dan

Tabel 3. Dimensi kemasan sekunder hasil rancangan mengurangi kerusakan buah salak selama transportasi. Penurunan mutu buah salah satunya disebabkan oleh penggunaan kemasan yang kurang diperhatikan keamanannya selama transportasi berlangsung (Albaar et al., 2015). Rais dan Sheroan (2015) menyatakan bahwa kehilangan pascapanen buah terjadi cukup besar yaitu 30-40\%. Kehilangan pascapanen menyebabkan kerugian bagi petani maupun eksportir, sehingga perlu penanganan khusus untuk mengurangi jumlah kehilangan pascapanen tersebut. Kerusakan mekanis buah dapat dikurangi dengan penggunaan kemasan transpotasi dan bantalan yang tepat (Chonhenchob dan Singh, 2003). Iswahyudi et al. (2015) menyarankan penggunaan kemasan transportasi berupa karton gelombang double wall flute $\mathrm{BC}$ sehingga mengurangi kerusakan fisik sebesar $13,17 \%$. Hasil perhitungan menggunakan persamaan-persamaan untuk perhitungan dimensi dalam, dimensi desain, dan dimensi luar kemasan sekunder disajikan pada Tabel 3 .

Desain kemasan sekunder hasil penelitian mempunyai dimensi $50 \times 34 \times 28 \mathrm{~cm}$ (body kemasan) dan $52 \times 36 \times 14 \mathrm{~cm}$ (cover kemasan). Kemasan sekunder yang dirancang berbahan karton gelombang double wall flute BC kraft $150 \mathrm{gsm}$ (tebal fute $0,7 \mathrm{~cm}$ ) dengan tipe kemasan PTD (Partial Telescope Design-Style Box) dimana terdiri dari bagian body dan cover (tutup) kemasan. Flute $\mathrm{BC}$ dapat meredam getaran dan guncangan selama transportasi. Jung et al. (2018) menyatakan bahwa terdapat pengaruh antara getaran dan tumpukan selama transportasi dengan penurunan mutu buah anggur. Bobot buah anggur menurun $6 \%$ dan terjadi penurunan Total Padatan Terlarut (TPT) $1,3{ }^{\circ}$ Brix akibat getaran, sehingga keberadaan kemasan yang dapat meredam getaran sangat diperlukan untuk mempertahankan mutu dan memperpanjang umur simpan buah.

\begin{tabular}{lcc}
\hline \multirow{2}{*}{ Parameter } & \multicolumn{2}{c}{ Bagian Kemasan } \\
\cline { 2 - 3 } Dimensi Dalam & Bottom (Body) & Top (Cover) \\
Panjang (cm) & & 49,34 \\
Lebar (cm) & 47,94 & 33,36 \\
Sh $(\mathrm{cm})$ & 31,96 & 13,57 \\
Tinggi $(\mathrm{cm})$ & 6,16 & 50,04 \\
Dimensi Desain & 27,14 & 34,06 \\
Panjang (cm) & & 6,86 \\
Lebar $(\mathrm{cm})$ & 48,64 & 14,27 \\
Sh $(\mathrm{cm})$ & 32,66 & 52,84 \\
Tinggi $(\mathrm{cm})$ & & 36,86 \\
Dimensi Luar & 27,84 & 14,97 \\
Panjang (cm) & & 1947,68 \\
Lebar $(\mathrm{cm})$ & 50,04 & 29156,81 \\
Tinggi $(\mathrm{cm})$ & 34,06 & \\
Luas Kemasan $\left(\mathrm{cm}^{2}\right)$ & 28,54 & 1704,36 \\
Volume kemasan $\left(\mathrm{cm}^{3}\right)$ & 48642,50 & \\
\hline
\end{tabular}



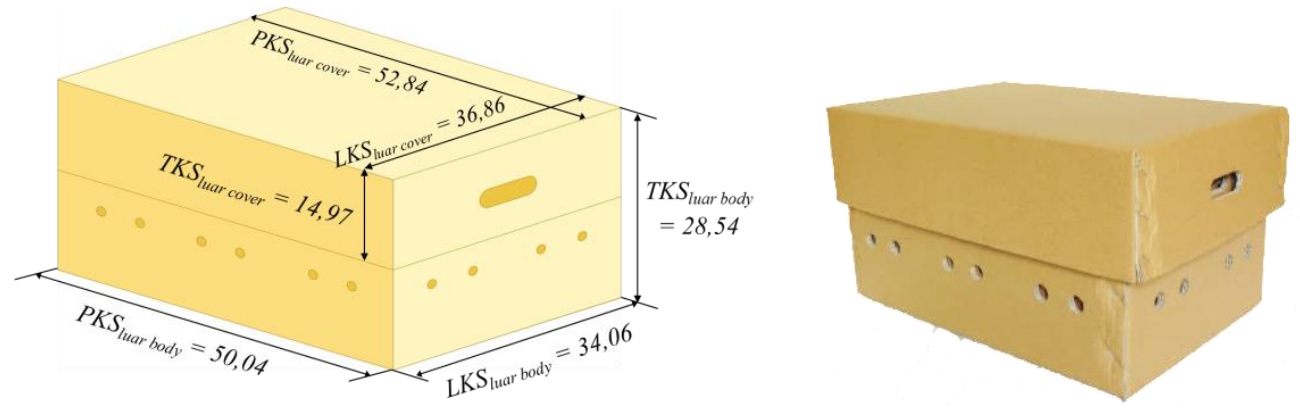

Gambar 11. Dimensi luar kemasan sekunder

Tipe kemasan PTD box mempunyai kekuatan kompresi yang sesuai untuk tumpukan kemasan. Desain kemasan tipe PTD mengacu pada gabungan flapsdi bagian sisi kemasan, bukan di bagian atas atau bawah. Kemasan sekunder diberi ventilasi berbentuk lingkaran 6 lubang pada sisi panjang dan 4 lubang di sisi lebar, serta diberi hand hole di bagian lebar kemasan. Singh et al. (2008) menyarankan ukuran lubang tangan $8,5 \mathrm{~cm} \times 2,5 \mathrm{~cm}$ dengan jarak sepertiga dari tinggi kemasan. Hilangnya kekuatan kemasan dengan ukuran handhole tersebut adalah sebesar $10 \%$ sampai $40 \%$. Kemasan sekunder mempunyai nilai kuat tekan kemasan maksimum 132,2 kgf dengan jumlah tumpukan maksimum 3-4 kemasan.

\section{Efisiensi Penataan Kemasan untuk Transportasi}

Efisiensi susunan kemasan di atas pallet maupun mobil pick up dapat diketahui dengan pengukuran luas kemasan, luas pallet, dan luas mobil pick up. Luas kemasan yang digunakan untuk perhitungan efisiensi yaitu luas kemasan sekunder bagian cover karena mempunyai panjang dan lebar paling besar dibandingkan kemasan lainnya.

\section{Efisiensi Penataan Kemasan pada Pallet}

Penataan kemasan di atas pallet dimaksudkan untuk keperluan ekspor, sehingga diketahui ukuran pallet yang cocok dengan kemasan hasil rancangan. Pallet merupakan alat bantu dalam distribusi terutama untuk tujuan ekspor (Qanytah dan Ambarsari, 2010), serta mempunyai peranan penting dalam penanganan dan pengangkutan produk dalam rantai pasokan (Roy et al., 2016). Simulasi penataan kemasan menggunakan beberapa ukuran pallet menurut standar International Organization for Standardization (ISO 6780, 2003) seperti pada Tabel 4 dan Gambar 12. Dengan ukuran pallet yang bervariasi maka efisiensi penataan kemasan juga akan beragam.

Tabel 4. Efisiensi penataan kemasan pada pallet

\begin{tabular}{clc}
\hline $\begin{array}{c}\text { Ukuran } \\
\text { pallet }(\mathbf{m m})\end{array}$ & \multicolumn{1}{c}{ Negara pengguna } & $\begin{array}{c}\text { Efisiensi penggunaan } \\
\text { pallet }(\boldsymbol{\%})\end{array}$ \\
\hline $1200 \times 800$ & Eropa, Singapura, China & 81,3 \\
$1140 \times 1140$ & Beberapa negara Eropa, China & 90,1 \\
$1200 \times 1000$ & Jerman, Belanda, Taiwan, Singapura, Thailand, China, Indonesia & 81,3 \\
$1219 \times 1016$ & Amerika Serikat, China & 78,8 \\
$1067 \times 1067$ & Amerika Serikat dan Kanada & 68,6 \\
$1100 \times 1100$ & Jepang, Taiwan, Korea, Singapura, thailand & 96,8 \\
\hline
\end{tabular}

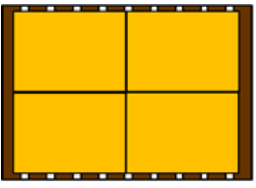

$1200 \times 800 \mathrm{~mm}$

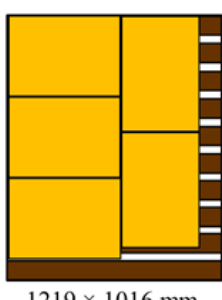

$1219 \times 1016 \mathrm{~mm}$

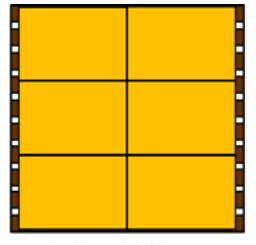

$1140 \times 1140 \mathrm{~mm}$

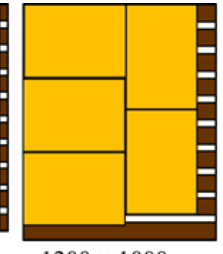

$1200 \times 1000 \mathrm{~mm}$

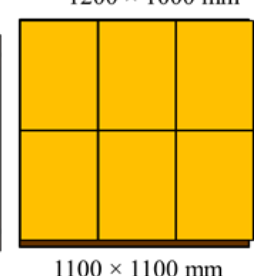

Gambar 12. Susunan kemasan sekunder pada berbagai ukuran pallet 
Efisiensi muatan pallet $90 \%$ atau lebih disebut good fit, efisiensi $80 \%$ disebut average fit, dan efisiensi muatan $70 \%$ termasuk poor fit (Lee, 2005). Tabel 4 menunjukkan bahwa dimensi kemasan distribusi hasil rancangan termasuk ke dalam average fit efisiensi pada pallet ukuran 1200 $\times 800 \mathrm{~mm}$ dan $1140 \times 1140 \mathrm{~mm}$. Oleh karena itu, kemasan distribusi ini dapat memenuhi kebutuhan untuk distribusi ke beberapa negara Eropa, Singapura, dan China yang selama ini negara-negara tersebut menjadi tujuan ekspor buah salak. Nilai efisiensi pallet ukuran $1100 \times 1100 \mathrm{~mm}$ termasuk kedalam good fit $(96,8 \%)$, namun terdapat susunan kemasan yang melebihi pallet (over-hang) sebesar 7 $\mathrm{mm}$ apabila dilakukan penyusunan 3 kemasan sekunder pada bagian lebar pallet. Selain nilai efisiensi, perlu dilihat susunan kemasan diatas pallet agar tidak terjadi over-hang dengan dasar pallet. Susunan kemasan yang melebihi pallet dapat mengurangi kekuatan tekan kemasan mencapai $13 \%$ (Singh et al., 2011). Hilangnya kekuatan kemasan mengakibatkan dinding kemasan tidak kuat menahan beban tumpukan, sehingga menimbulkan resiko roboh selama penanganan maupun penyimpanan.

Penggunaan pallet sangat penting sebagai satuan handling, karena menurut Roy et al. (2016) menyatakan bahwa penanganan material dan logistik berjalan efisien dengan menggunakan pallet yang sesuai dengan standar masing-masing negara. Pengguanaan pallet dapat meminimasi waktu pemuatan dan pengiriman, serta memaksimalkan efisiensi gudang (Cinar et al., 2017). Penggunaan pallet dapat menghemat biaya $\$ 2,60$ juta/tahun di Singapura pada tahun 2003. Proses bongkar muat
13.000 kemasan kardus yang berisi kaleng makanan secara manual membutuhkan waktu 3 hari, dan hanya 4 jam apabila menggunakan pallet dengan bantuan forklift. Oleh karena itu penggunaan pallet juga dapat meningkatkan produktivitas dan efisiensi kerja (Hartati, 2007).

\section{Efisiensi Penataan Kemasan Pada Mobil pick up}

Pengiriman salak di Banjarnegara biasanya menggunakan mobil pick up atau truk untuk alat transportasi lokal maupun luar kota, hal ini juga menyesuaikan dengan kuantitas salak yang akan dikirim. Dimensi dan cara penyusunan kemasan mempengaruhi pemanfaatan ruang bak pick-up (Iswahyudi et al., 2015). Beberapa mobil pick up yang sering digunakan untuk pengangkutan antara lain seperti pada Tabel 5 dan Gambar 13.

Analisis efisiensi penataan kemasan di atas bak pick up dimaksudkan untuk mengetahui muatan pengiriman, dengan tujuan efisiensi distribusi buah yang dijual sehingga dapat memaksimalkan pengiriman (Qanytah dan Ambarsari, 2011). Hasil perhitungan efisiensi menunjukkan bahwa secara keseluruhan kemasan sekunder/distribusi hasil rancangan dapat didistribusikan menggunakan hampir semua jenis mobil pick-up dengan efisiensi lebih dari $90 \%$ (good fit). Jenis mobil yang disarankan untuk distribusi yaitu jenis mobil A dan D, karena pada mobil B terdapat ruang kosong yang dapat memungkinkan kemasan roboh selama transportasi. Nilai efisiensi yang berbeda disebabkan oleh dimensi dan cara penyusunan kemasan sehingga mempengaruhi pemanfaatan ruang bak pick-up (Iswahyudi et al., 2015).

Tabel 5. Efisiensi penataan kemasan pada berbagai jenis pick up

\begin{tabular}{ccccc}
\hline \multirow{2}{*}{ Jenis Mobil } & \multicolumn{2}{c}{ Ukuran Bak $(\mathbf{m m})$} & \multirow{2}{*}{ Jumlah Kemasan } & \multirow{2}{*}{ Efisiensi (\%) } \\
\cline { 2 - 3 } & Panjang & Lebar & 16 & 95,9 \\
A & 2200 & 1480 & 18 & 91,5 \\
B & 2630 & 1460 & 16 & 83,9 \\
C & 2350 & 1585 & 18 & 90,6 \\
D & 2425 & 1600 & 16 & 89,6 \\
E & 2200 & 1585 & & \\
\hline
\end{tabular}

A

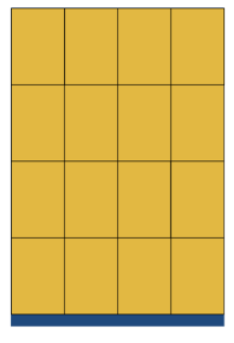

B

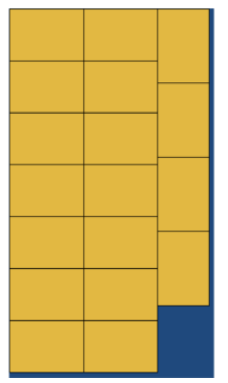

C

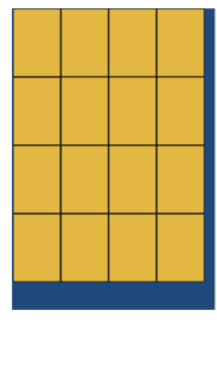

D

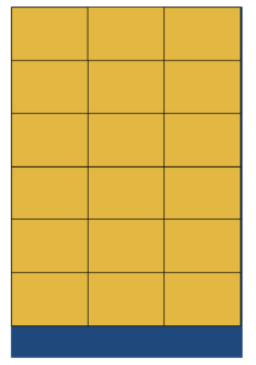

E

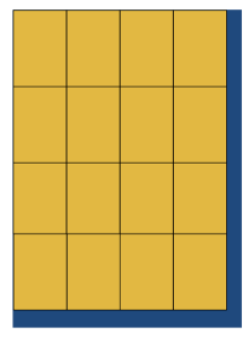

Gambar 13. Penataan kemasan hasil rancangan pada berbagai mobil pick up tampak atas untuk layer pertama 


\section{KESIMPULAN DAN SARAN}

\section{Kesimpulan}

Desain kemasan primer berukuran $15,98 \times$ $15,98 \times 18,48 \mathrm{~cm}$ atau disesuaikan menjadi $16 \times 16$ $\times 18,5$. Nilai kuat tekan maksimum kemasan sebesar 65 kgf yang mampu menumpuk 23-43 kemasan primer. Desain kemasan sekunder berukuran 50,04 $\times$ $34,06 \times 28,54 \mathrm{~cm}$ untuk body kemasan, dan 52,84 $\times$ $36,86 \times 14,97 \mathrm{~cm}$ untuk cover kemasan. Nilai kuat tekan maksimum kemasan sekunder sebesar 132,2 kgf yang mampu menahan 3-4 tumpukan untuk kapasitas buah maksimal $12 \mathrm{~kg}$. Dimensi kemasan sekunder/distribusi termasuk ke dalam good fit efisiensi pada pick-up (tipe A dan D) dan average fit efisiensi pada pallet (ukuran $1200 \times 800$ dan $1140 \times$ $1140 \mathrm{~mm}$ ), sehingga dapat memenuhi kebutuhan untuk distribusi lokal maupun ekspor ke beberapa negara Eropa, Singapura, dan China.

\section{Saran}

Perlu dilakukan pengujian transpotasi/ distribusi buah salak secara langsung menggunakan kemasan hasil rancangan untuk mengetahui perubahan mutu dan umur simpan buah setelah transportasi. Preferensi konsumen juga perlu dilakukan untuk mengetahui apakah sistem kemasan ini dapat diterima oleh konsumen.

\section{UCAPAN TERIMA KASIH}

Terima kasih kepada Departemen Teknologi Industri Pertanian, Institut Pertanian Bogor atas bantuan dana penelitian melalui program bantuan biaya penelitian program Magister tahun 2016.

\section{DAFTAR PUSTAKA}

Adiharmanto KA, Hartanto R, dan Novita DD. 2013. Perubahan kimia dan lama simpan buah salak pondoh (Salacca edulis Reinw) dalam penyimpanan dinamis udara $\mathrm{CO}_{2}$. Jurnal Keteknikan Pertanian. 2(3):123- 132.

Albaar N, Budiastra IW, dan Hariyadi Y. 2015. Influence of secondary packaging on quality of carrots during transportation. Agriculture and Agricultural Science Procedia. 9 : 348 352.

Cahyono B. 2016. Panen Untung dari Budi Daya Salak Intensif. Yogyakarta (ID): Lily Publisher.

Cinar D, Oliveira JA, Topcu YI, Pardalos PM. 2017. Scheduling the truckload operations in automated warehouse with alternative aisles for pallets. Journal Applied Softwer Computing. $52: 566-574$.

Chonhenchob V dan Singh SP. 2003. A Comparison of corrugated boxes and reusable plastic containers for mango distribution. Journal
Packaging Technology and Scince. 16 (6): 231-237.

Dehankar RN, Langde AM, Siddiqui S, Tidke DJ. 2014. Review on paper corrugated box manufacturing used in goods packaging. international conference on advantages in engineering dan technology. IOSR-JMCE. 2320-334X:28-30.

Hartati S. 2007. Standar Global untuk Efisiensi Supply Chain II [Internet]. [2007 Oktober 10]. Jakarta (ID). Tersedia pada: http://www.gs1.or.id/news_main.php?. [2017 Desember 20].

[ISO] International Organization for Standardization. 2003. Flat pallet for intercontinental materials handling-Principal dimensions and tolerance [internet]. Tersedia dari https://www.iso.org/standard/30524.html. [2018 Februari 22].

Iswahyudi, Darmawati E, dan Sutrisno. 2015. Perancangan kemasan transportasi buah jambu air (Syzygium equeum) cv Camplong. Jurnal Keteknikan Pertanian. 3(1):65-72.

Jung MJ, Lee S, Lee WH, Cho BK, Lee SH. 2018. Effect of vibration stress on quality og packaged grapes during transportation. Journal Engineering in Agriculture, Environment and Food. 11 (2): 43-49.

Kementerian Pertanian. 2015. Rencana Strategis Kementerian Pertanian Tahun 2015-2019 [Internet]. [2015 April 06, Kementerian Pertanian]. Jakarta (ID): Renstra Kementan. hlm 1-339; $\quad$ Tersedia pada: http://www.pertanian.go.id/file/ RENSTRA_2015-2019.pdf [2016 Desember 23].

Lee MH. 2005. Export packaging for agricultural products. institute of korea packaging systems.

Napitupulu B, Murizaf S, Zulkarnain DH, Tampubolon M. 2001. Karakteristik teknologi pasca panen pengemasan buah salak sidimpuan. balai pengkajian teknologi pertanian gedung johor. Balai Penelitian dan Pengembangan Pertanian, Departeman Pertanian.

Nordstrand T. 2003. Basic Testing and Strength Design of Corrugated Boardand Containers. Sweden : KFS i Lund AB.

Opara UL dan Fadiji T. 2018. Compression damage susceptibility of apple fruit packaged inside ventilated corrugated paperboard package. Journal Scienta. 227 (2018): 154-161.

Pangidoan S, Sutrisno, dan Purwanto A. 2013. Simulasi transportasi dengan pengemasan untuk cabai merah keriting segar. Jurnal Keteknikan Pertanian. 27(1): 69-76.

Pathare PB dan Opara UL. 2014. Structural design of corrugated boxes for horticultural produce 
: A review. Journal Biosystems Engineering. $125: 128-140$.

Qanytah dan Ambarsari A. 2010. Efisiensi penggunaan kemasan kardus distribusi mangga arumanis. Jurnal Litbang Pertanian. 30(1):8-15.

Rais M dan Sheoran A. 2015. Scope of supply chain management in fruit and vegetables in India. Journal Food Processing \& Technology. 6 (3): 427-434.

Roy D, Carrano AL, Pazour JA, Gupta A. 2016. Cost-effectivw pallet management strategies. Transportation Research Part E: Logistics and Transportation Review. 93 (2016): 358371.

SinghJ, Olsen E, Singh SP, Manley J, Wallance F. 2008. The effect of ventilation and hand holes on loss of compression strength in corrugated boxes. Journal Applied Packaging Research. 2(4):227-238.

Singh J, Kisch R, Chhun J, Olsen E. 2009. Designan opportunity in reducing corrugated fiberboard carbon footprint. Journal Applied Packaging Research. 3(2):105-118.

Singh SP, Singh J, dan Saha K. 2011. Effect of palletized box offset on compression strength of unitized and stacked empty corrugated fiberboard boxes. Journal Applied Packaging Research. 5(3): 157-167.

Sutrisno, Darmawati E, dan Sukmana D. 2011. Rancangan Kemasan Berbahan Karton Gelombang untuk Individual Buah Manggis (Garcinia mangostana L.). Prosiding Kajian Teknik Pasca Panen dan Proses Hasil Pertanian. Jember, Indonesia. 21-22 Juli 2011.

Tawakal MI, Darmawati E, dan Sutrisno. 2016. Transportation packaging design for papaya (Carica papaya L.) IPB 9. The 2nd International Symposium on Agricultural and Biosystem Engineering. 2016 August 911; Lombok. ISBN 978-602-14315-2-8.

Trisnawati W dan Rubiyo. 2004. Pengaruh penggunaan kemasan dan lama penyimpanan terhadap mutu buah salak Bali. Jurnal Pengkajian dan Pengembangan Teknologi Pertanian. 7(1) : 76-82.

Yulianti N, Sutrisno, dan Darmawati E. 2010. Improvement of the technology packaging forthe transportation of mangosteen. dalam penyimpanan dinamis udara $\mathrm{CO}_{2}$. Jurnal Keteknikan Pertanian. 4(1) : 55-60. 